\title{
On the 'Inherent' Character of the Right of States to Self-defence
}

\author{
Marco Roscini*
}

\begin{abstract}
While there is no lack of studies on the use of armed force by states in self-defence, its qualification as an 'inherent right' in article 51 of the Charter of the United Nations has received little scholarly attention and has been too quickly dismissed as having no significance. The present article fills this gap in the literature. Its purpose is not to discuss the limits to which article 51 or customary international law submit the exercise of the right of self-defence by states, but to examine what its 'inherent' character means and what legal consequences it entails. The article advances two main arguments. The first is that self-defence is a corollary of statehood as presently understood because it is essential to preserving its constitutive elements. The second argument is that the exercise of the right of self-defence must be distinguished from the right itself: it is only the former that may be delegated to other states or submitted to limitations under customary international law and treaty law. The right of self-defence, however, cannot be alienated and it takes precedence over other international obligations, although not over those specifically intended to limit the conduct of states in armed conflict or over non-derogable human rights provisions.
\end{abstract}

\section{Keywords}

Inherent Right, Inalienable Right, Fundamental Right, Self-defence, Collective Security, Use of Force, Natural Law, Positivism, Article 51, United Nations Charter, Jus ad Bellum, Self-preservation, International Law

\section{Introduction}

My starting point is that, while there is no self-standing distinct category of 'fundamental' rights of states ontologically different from or hierarchically superior to other non-

* Professor of International Law, University of Westminster (UK). I am grateful to the anonymous peer reviewers for their valuable comments, and to Niki Aloupi, Jean d'Aspremont, Helmut Philipp Aust, Daniel H Joyner, Stephen C Neff, Antonios Tzanakopoulos and Jure Vidmar for providing feedback on my article during the workshop in Tuscaloosa (Alabama) in April 2015. I am also grateful to Derek Hird (University of Westminster), Sherif Elgebeily (University of Hong Kong) and Eliza Watt (University of Westminster) for their help with identifying the most accurate translation of the Arabic, Chinese and Russian texts of art 51 of the Charter of the United Nations. 
fundamental rights, there are treaty and customary rules, framed in terms of rights and duties, which attach special characteristics to certain rights and duties. The problem, therefore, is essentially one of interpretation, ie to establish the meaning of adjectives like 'inalienable', 'permanent' or, in our case, 'inherent' as used in treaty and/or customary law provisions.

While there is no lack of studies on the use of armed force by states in self-defence, its qualification as an 'inherent right' in article 51 of the Charter of the United Nations (UN Charter) has received little scholarly attention and has been too quickly dismissed as 'merely a remnant of the natural law origin of the concept of self-defence.' The present article intends to fill this gap in the literature. Its purpose is not to discuss the limits to which article 51 or customary international law submit the exercise of self-defence by states, but to examine what its 'inherent' character means and what legal consequences, if any, it entails. This article advances two main arguments. The first is that, whichever approach one takes to international law (naturalistic or positivistic), self-defence is a corollary of statehood as presently understood, and is as such inalienable. The second argument is that the exercise of the right of self-defence must be distinguished from the right itself: it is only the former that may be submitted to limitations or delegated to other states.

To demonstrate these arguments, this article proceeds as follows. It starts with an account of the history of the right of states to self-defence. It then discusses the meaning of 'inherent right' as used in article 51 of the UN Charter. Finally, it examines the possible consequences arising from such inherent character, in particular its inalienability and its prevalence over other international obligations, as well as its relationship with the collective security system under chapter VII of the UN Charter. One point on terminology: whether self-defence is a right stricto sensu, ${ }^{2}$ a privilege or liberty, ${ }^{3}$ a circumstance precluding wrongfulness of conduct, ${ }^{4}$ a principle or a general principle of law, ${ }^{5}$ a limitation to the prohibition of the use of force of which it forms an integral

1 Tom Ruys, 'Armed Attack' and Article 51 of the UN Charter (CUP 2013) 66; Charter of the United Nations (adopted 26 June 1945, entered into force 24 October 1945) 1 UNTS XVI (UN Charter). See also Albrecht Randelzhofer and Georg Nolte, 'Article 51' in Bruno Simma and others (eds), The Charter of the United Nations-A Commentary, vol 2 (3rd edn, OUP 2012); Yoram Dinstein, War, Aggression and Self-Defence (5th edn, CUP 2011) 191, who qualifies the expression as 'an anachronistic residue from an era in which international law was dominated by ecclesiastical doctrines'.

2 Stephen C Neff, 'The Dormancy, Rise and Decline of Fundamental Liberties of States' (2015) 4 CJICL 482.

3 Derek W Bowett, Self-Defence in International Law (Manchester UP 1958) 8-9, 269.

4 International Law Commission (ILC), Responsibility of States for Internationally Wrongful Acts, UNGA Res 56/83 (28 January 2002) UN Doc A/RES/56/83 (ILC Articles on State Responsibility) art 21. Thouvenin argues that self-defence is a circumstance precluding wrongfulness in relation to conventional obligations other than art 2(4) of the UN Charter, but is a subjective right when it entails the use of armed force: JeanMarc Thouvenin, 'Circumstances Precluding Wrongfulness in the ILC Articles on State Responsibility: Self-Defence' in James Crawford, Alain Pellet and Simon Olleson (eds), The Law of State Responsibility (OUP 2010).

5 Legality of the Threat or Use of Nuclear Weapons (Advisory Opinion) [1996] ICJ Rep 226 (Nuclear Weapons) 308-309 (Judge Fleischhauer); Shabtai Rosenne, 'Self-Defence and the Non-Use of Force: Some Random Thoughts' in Arthur Eyffinger, Alan Stephens and Sam Muller (eds), Self-Defence as a Fundamental Principle (Hague Academic Press 2009) 64. 
part $^{6}$ or a de facto condition ${ }^{7}$ is in the end a question of little practical relevance, ${ }^{8}$ and would be of no avail to discuss it here. This article, therefore, will descriptively refer to self-defence as a right, as does article 51 of the UN Charter.

\section{A brief history of the right of states to self-defence}

The right of states to individual and collective self-defence has developed by analogy from the right of individuals to defend themselves and others under criminal law. ${ }^{9}$ The classical scholars of international law saw it as a right conferred by nature not only upon individuals, but also upon states. ${ }^{10}$ Reacting against aggression, or against a threat thereof, was consistently considered a cause for just war when waged both by princes and by individuals. ${ }^{11}$ Vitoria relied on the writings of Augustine and Thomas Aquinas to argue that 'a wrong received' is the 'single and only just cause for commencing a war. ${ }^{12}$ Similarly, Ayala found defensive wars 'open to any one by the law of nature. ${ }^{13}$ For Gentili, 'necessary defence' is 'the most generally accepted of all rights' both for individuals and states: 'All laws and all codes allow the repelling of force by force. There is one rule which endures for ever, to maintain one's safety by any and every means. ${ }^{\text {'1 }}$

6 Hans Kelsen, 'The Draft Declaration on Rights and Duties of States: Critical Remarks' (1950) 44 AJIL 259, 265; Jean d'Aspremont, 'Mapping the Concepts Behind the Contemporary Liberalization of the Use of Force in International Law' (2009-10) 31 U Pennsylvania J Intl L 1089, 1106.

7 Roberto Ago, 'Addendum to Eighth Report on State Responsibility' ILC YB 1980/II(1) 53.

8 See, eg, Dinstein (n 1) 189-90.

9 On the interactions between self-defence in domestic criminal law (both in civil and common law jurisdictions) and in international law, see George P Fletcher and Jens D Ohlin, Defending Humanity: When Force is Justified and Why (OUP 2008). On anthropomorphic thinking in international law, see Jean d'Aspremont's and Helmut Philipp Aust's contributions to this special issue: Jean d'Aspremont, 'The Doctrine of Fundamental Rights of States and Anthropomorphic Thinking in International Law' (2015) 4 CJICL 501; Helmut Philipp Aust, 'Fundamental Rights of States: Constitutional Law in Disguise?' (2015) 4 CJICL 521.

10 The right of states to self-defence had a broader content than the right of individuals, as it allowed a forceful reaction against attacks that were not only ongoing, but also imminent, and even against those that had already occurred in order to prevent further attacks and punish the enemy. See, eg, Emer de Vattel, The Law of Nations, or, the Principles of the Law of Nature, Applied to the Conduct and Affairs of Nations and Sovereigns, with Three Early Essays on the Origin and Nature of Natural Law and on Luxury (first published 1758, Béla Kapossy and Richard Whatmore eds, Liberty Fund 2008) book 2, ch IV, 289, para 50; Christian Wolff, Jus Gentium Methodo Scientifica Pertractatum (first published 1764, Joseph H Drake tr, Wildy \& Sons 1964) vol 2, 129, para 272.

11 Peter Haggenmacher, 'Self-Defence as a General Principle of Law and its Relation to War' in Arthur Eyffinger, Alan Stephens and Sam Muller (eds), Self-Defence as a Fundamental Principle (Hague Academic Press 2009) 21. The medieval notion of 'war' included not only that waged by the emperor or independent princes, but also by private individuals (ibid). The jus bellandi of private persons was famously rejected in Jean-Jacques Rousseau, Du Contrat Social (first published 1762, reprinted in Jean-Jacques Rousseau, The Social Contract and The Discourses (George D H Cole tr, D Campbell Publishers 1993)) book I, ch IV, 187.

12 Francisco de Vitoria, De Jure Belli (first published 1539, reprinted in Ernest Nys (ed), De Indis et de Iure Belli Relectiones (Carnegie Institution of Washington 1917)) 170.

13 Balthazaris Ayala, De Jure et Officiis Bellicis et Disciplina Militari Libri III (first published 1582, John Westlake ed, The Lord Baltimore Press 1912) vol II, 9.

14 Alberico Gentili, De Jure Belli Libri Tres (first published 1598, John C Rolfe tr, Humphrey Milford 1933) book I, ch XIII, 59. 
Suárez also viewed self-defence as a 'natural and necessary' right, to be exercised with moderation. ${ }^{15}$ According to Grotius, defence was one of the three just causes for public war together with recovery of property and punishment. ${ }^{16}$ In his view, the right of selfdefence $(. .$.$) has its origin directly, and chiefly, in the fact that nature commits to each$ his own protection, not in the injustice or crime of the aggressor. ${ }^{17}$ Vattel emphasised that '[e]very nation, as well as every man, has (...) a right to prevent other nations from obstructing her preservation, her perfection, and happiness - that is, to preserve herself from all injuries.' ${ }^{18} \mathrm{He}$ referred to this right as the 'right to security' (droit de sûreté). ${ }^{19}$ In Wolff's view, 'The right belongs to every nation to defend itself and its right against another nation. For the right of self-defence belongs to everybody. ${ }^{20}$

Until the beginning of the twentieth century, however, self-defence was largely identified with the broader right of states to self-preservation, which was in turn based on the right of states to existence. ${ }^{21}$ The two terms, therefore, were often used interchangeably. ${ }^{22}$ Self-preservation was closely linked to the doctrine of necessity and was thus a much broader right than self-defence, as it included the right to use forcible measures to react not only against an attack but in any situation where the security of the state was threatened. ${ }^{23}$ The confusion between self-preservation and self-defence is still evident in the letter dated 6 February 1838 sent from the British Ambassador in Washington, Fox, to the US Secretary of State, Forsyth, where he justified the sinking of the Caroline on the basis of the "piratical character of the steamboat "Caroline" and the

15 Francisco Suárez, 'The Three Theological Virtues: On Charity' in Gwladys L Williams, Ammi Brown and John Waldron (eds), Selection from Three Works of Francisco Suárez, SJ (first published 1621, Humphrey Milford 1944) vol II, Disputation XIII, 803-04, ss I(4) and I(6).

16 Hugo Grotius, De Jure Belli ac Pacis (first published 1625, Francis W Kelsey tr, Wildly \& Sons 1964) book II, ch 1, 171, para II.

17 ibid 172, para III.

18 Vattel (n 10) 288, para 49.

19 ibid.

20 Wolff (n 10) 139, para 273.

21 Pierluigi Lamberti Zanardi, La Legittima Difesa nel Diritto Internazionale (Giuffré 1972) 9; Stanimir A Alexandrov, Self-Defense against the Use of Force in International Law (Kluwer Law International 1996) 23. Fenwick identifies the right of self-preservation with the right of existence and sees self-defence as an 'inferential right associated with it': Charles G Fenwick, International Law (2nd edn, George Allen \& Unwin Ltd 1924) 142. According to the Greek delegate at the ILC, 'The right to exist implies the right to maintain existence': ILC, 'Preparatory Study Concerning a Draft Declaration on the Rights and Duties of States, Memorandum Submitted by the Secretary-General' (15 December 1948) UN Doc A/CN.4/2, 49. On the right of states to exist, see Jure Vidmar's article in this special issue: Jure Vidmar, 'The Concept of the State and its Right of Existence' (2015) 4 CJICL 547.

22 Ian Brownlie, 'The Use of Force in Self-Defence' (1961) 37 BYIL 183, 186, 189; Stephen C Neff, War and the Law of Nations (CUP 2005) 241. Self-preservation should be distinguished from self-help: 'While selfpreservation has a mainly defensive connotation, self-help is distinctly active since it aims at the pursuit of a right': Haggenmacher (n 11) 9. See also Lamberti Zanardi (n 21) 35-36. Bowett also distinguishes self-defence from self-help: although they both imply a previous illegal act by the state against which they are directed, the former has a defensive function, while the latter has a 'remedial or repressive character in order to enforce legal rights': Bowett (n 3) 11. In contrast, see Ago (n 7) 56-57. The legality of coercive self-help measures has been rejected by the International Court of Justice (ICJ). See Corfu Channel (UKv Albania) (Merits) [1949] ICJ Rep 4, 35.

23 Brownlie (n 22) 185. 
necessity of self-defence and self-preservation. ${ }^{24}$ In his letter addressed to Fox, the new US Secretary of State, Webster, also employed the self-defence/self-preservation language interchangeably when he stated that '[a] just right of self-defence attaches always to nations as well as to individuals, and is equally necessary for the preservation of both. ${ }^{25}$ Even in the UN Charter era, references that mixed self-defence with self-preservation have not disappeared. ${ }^{26}$ In its statement before the Security Council in relation to the destruction of the Osirak nuclear reactor in Iraq in 1981, for instance, Israel claimed that it

performed an elementary act of self-preservation, both morally and legally. In so doing, Israel was exercising its inherent right of self-defence as understood in general international law and as preserved in Article 51 of the Charter of the United Nations. ${ }^{27}$

Self-defence/self-preservation was consistently seen as a 'fundamental right' of states. In the Hobbesian state of nature among sovereigns, the absence of a supreme authority made self-preservation, as provided by natural law, the most important principle. ${ }^{28}$ Locke refers to self-preservation as a 'fundamental law of Nature' that prevails over any other duty towards others. ${ }^{29}$ After the advent of positivism in the nineteenth century, scholars continued to see it as a fundamental right. For Wheaton, self-preservation, of which self-defence is a subsidiary right, is 'one of the most essential and important' among the 'absolute international rights of States' and 'that which lies at the foundation of all the rest. ${ }^{30}$ Rivier maintains that self-preservation is 'le premier des droits essentiels; il les résume tous. ${ }^{31}$ Similarly, Calvo identifies in the 'right of conservation' ' $[u] n$ des droits essentiels inhérents à la souveraineté et à l'indépendence des États' and qualifies it as 'le premier de tous les droits absolus ou permanents. ${ }^{32}$ According to Hall, 'In the last resort almost the whole of the duties of states are subordinated to the right of selfpreservation.' 33

It should be noted that, in the pre-Charter era, self-preservation/self-defence was often seen not only as a fundamental right, but also as a duty. Vattel, for instance, states that '[s] elf-defence against unjust violence is not only the right but the duty of a

24 Robert Y Jennings, ‘The Caroline and McLeod Cases' (1938) 32 AJIL 82, 85.

25 ibid 91.

26 In literature, see for instance Bin Cheng, who includes self-defence in the chapter on the principle of self-preservation: Bin Cheng, General Principles of Law as Applied by International Courts and Tribunals (Grotius Publications Ltd 1987) 29ff.

27 UNSC Verbatim Record (12 June 1981) UN Doc S/PV.2280, reprinted in (1981) 20 ILM 970. However, the operation was generally condemned, including by the UN Security Council: UNSC Res 487 (19 June 1981) UN Doc S/RES/487 (adopted unanimously).

28 Thomas Hobbes, Leviathan (first published 1651, CUP 1904) 81-86. See Neff, War and the Law of Nations (n 22) 133.

29 John Locke, Two Treaties of Civil Government (first published 1690, JM Dent \& Sons 1924) book II, ch III, 125, s 16.

30 Henry Wheaton, Elements of International Law (6th edn, Little Brown \& Co 1857) 86-87.

31 Alphonse Rivier, Principes du Droit des Gens (Arthur Rousseau Éditeur 1896) vol I, 257.

32 Charles Calvo, Le Droit International Théorique et Pratique (2nd edn, Durant et Pedone-LaurielGuillaumin 1870) vol I, 258.

33 Alexander P Higgins (ed), Hall's International Law (8th edn, Clarendon Press 1924) 322. 
nation, and one of her most sacred duties.' ${ }^{34}$ Similarly, according to Wolff, 'Every nation is bound to save itself by the law of nature itself. ${ }^{35}$ For Wheaton, self-preservation is a duty that a state owes not only to other states, but also to its own members, and the most solemn and important. ${ }^{36}$ The Virginius correspondence also emphasised that the right of self-preservation and of self-defence (...) is a right with respect to other countries, and one of the most solemn and sacred of the duties of any state with relation to its citizens. ${ }^{37}$

With the progressive restriction of the broader right of self-preservation, that culminated with the adoption of the UN Charter, the narrower right of self-defence came to have its own separate identity and to be seen as the only admissible form of self-preservation, ie as a defensive measure against an unlawful use of force. ${ }^{38}$ If, in the classical era, self-preservation was a ground for a just war and, with the abandonment of the bellum justum doctrine in the 1800s, an essentially political justification for a de jure war and one of the grounds for adopting 'measures short of war, ${ }^{39}$ then, with the consolidation of a prohibition on the use of force in the first half of the twentieth century self-defence became the only basis for a lawful use of force under customary international law. Writing as early as 1905, Oppenheim recalls that '[s] uch acts of violence in the interest of self-preservation are exclusively excused as are necessary in self-defence. ${ }^{40}$ Westlake confirms that 'the true international right of selfpreservation is merely that of self-defence. ${ }^{41}$ For Kelsen, self-defence is a lawful form of self-help against a specific violation of international law, ie an illegal use of force. ${ }^{42}$ The affirmation of a prohibition on the use of force also determined that self-defence came to be regarded not only as a right, but also as a circumstance precluding the wrongfulness of conduct. ${ }^{43}$

34 Vattel (n 10) book III, s III, para 487, 35; book I, ch II, 87, para 16.

35 Wolff (n 10) para 23, 31.

36 Wheaton (n 30) 86.

37 Virginius Correspondence No 46 from Mr Cushing to Mr Fish (5 December 1874) 109.

38 Brownlie (n 22) 203, 210-11 ('it is difficult to assume that States individually continued to equate the right of legitimate defence with self-help at a time when the illegality of self-help was increasingly apparent'); Rosalyn Higgins, The Development of International Law Through the Political Organs of the United Nations (OUP 1963) 216. As Dinstein notes, 'The evolution of the idea of self-defense in international law goes hand in hand with the prohibition of aggression': Dinstein (n 1) 189. For Jennings, 'it was in the Caroline case that self-defence was changed from a political excuse to a legal doctrine': Jennings (n 24) 82. Haggenmacher, however, sees the Caroline incident as a manifestation of self-help, although he acknowledges that the involved parties saw it as a case of self-defence and self-preservation: Haggenmacher (n 11) 10-11.

39 Dinstein (n 1) 188; Carlo Focarelli, Introduzione Storica al Diritto Internazionale (Giappichelli 2012) 345-46; Bowett (n 3) 117; Lamberti Zanardi (n 21) 7-8, 18-20, 40; Arthur Eyffinger, 'Self-Defence or the Meanderings of a Protean Principle' in Arthur Eyffinger, Alan Stephens and Sam Muller (eds), Self-Defence as a Fundamental Principle (Hague Academic Press 2009) 123-24.

40 Lassa Oppenheim, International Law: A Treatise, vol 1 (Longmans Green and Co 1905) 178.

41 John Westlake, International Law (CUP 1904) pt I, 312.

42 Hans Kelsen, 'Collective Security and Collective Self-Defense under the Charter of the United Nations' (1948) 42 AJIL 783, 783-84.

43 Thouvenin (n 4) 460. 
The gradual emergence of restrictions to the use of armed force by states, then, did not impair the right of states to self-defence. Although it did not contain a general prohibition of the use of armed force but merely submitted it to procedural conditions, the 1919 Covenant of the League of Nations implicitly recognised the right of a state to use defensive force in article 8, which allowed states to maintain armaments to the level 'consistent with national safety. ${ }^{44}$ It also provided for a collective self-defence mechanism in article 10. The first multilateral treaty codification of the right of self-defence is in article 2 of the 1925 Locarno Pact, according to which the non-aggression obligation contained therein does not prejudice

[t]he exercise of the right of legitimate defence, that is to say, resistance to a violation of the undertaking contained in the previous paragraph or to a flagrant breach of articles 42 or 43 of the said Treaty of Versailles, if such breach constitutes an unprovoked act of aggression and by reason of the assembly of armed forces in the demilitarised zone immediate action is necessary. ${ }^{45}$

In 1928, the General Treaty for the Renunciation of War as an Instrument of National Policy (Pact of Paris) was signed. ${ }^{46}$ Although its article 1 provides that ' $\mathrm{t}$ ] he High Contracting Parties solemnly declare in the names of their respective peoples that they condemn recourse to war for the solution of international controversies, and renounce it, as an instrument of national policy in their relations with one another', the treaty does not contain any provision on self-defence. In ratifying it, however, France maintained that 'each country should retain the right of legitimate defence. ${ }^{47}$ The British, Irish, Japanese and South African governments made similar declarations, with South Africa explicitly referring to legitimate self-defence as a natural right. ${ }^{48}$ In response to these concerns, the US Note of 23 June 1928 stated as follows:

44 Covenant of the League of Nations (adopted 28 June 1919, entered into force 10 January 1920) 225 CTS 195.

45 Treaty of Mutual Guarantee and Final Protocol of the Locarno Conference (adopted 16 October 1925, entered into force 14 September 1926) 54 LNTS 291 (Locarno Pact). 1924 Geneva Protocol for the Pacific Settlement of International Disputes, art 2 also exempted the 'case of resistance to acts of aggression' from the signatories' commitment not to resort to war against one another or against a state that had accepted the Protocol obligations. See Geneva Protocol for the Pacific Settlement of International Disputes (opened for signature 2 October 1924) 1008 LNOJ 1521, Doc No C.606.M.211.1924.IX. The Protocol, however, never entered into force. Other treaties also expressly mentioned the right of self-defence. The 1937 Saadabad Treaty of Non-Aggression between Iran, Iraq, Afghanistan and Turkey, art 4, for instance, expressly excluded that 'the exercise of the right of legitimate self-defence, that is to say, resistance to an act of aggression' amounted to an act of aggression itself. See Saadabad Treaty of Non-Aggression between Iran, Iraq, Afghanistan and Turkey (adopted 8 July 1937, entered into force 25 June 1938) 190 LNTS 21, art 4 .

46 General Treaty for the Renunciation of War as an Instrument of National Policy (adopted 27 August 1928, entered into force 24 July 1929) 94 LNTS 57 (Pact of Paris).

47 Quoted in Rosalyn Higgins (n 38) 205, fn 78.

48 Brownlie (n 22) 205-06. In response to a questionnaire prepared by the Secretariat of the League of Nations in relation to a possible amendment to the Covenant to harmonise it with the Pact of Paris, Germany also pointed out that ' $[\mathrm{t}$ ]hough mentioned neither in the Covenant not the Pact, the right of a nation to defend itself against attack was indisputable. It derived from a natural law which had greater force than any convention': LNOJ, Special Supplement No 94, 41 (emphasis added). 
There is nothing in the American draft of an anti-war treaty which restricts or impairs in any way the right of self-defense. That right is inherent in every sovereign state and is implicit in every treaty. Every nation is free at all times and regardless of treaty provisions to defend its territory from attack or invasion and it alone is competent to decide whether circumstances require recourse to war in self-defense. If it has a good case, the world will applaud and not condemn its action. Express recognition by treaty of this inalienable right, however, gives rise to the same difficulty encountered in any effort to define aggression. It is the identical question approached from the other side. Inasmuch as no treaty provision can add to the natural right of self-defense, it is not in the interest of peace that a treaty should stipulate a juristic conception of self-defense since it is far too easy for the unscrupulous to mold events to accord with an agreed definition. ${ }^{49}$

The Note was sent to fourteen states, ${ }^{50}$ which accepted or noted the interpretation of the Pact of Paris purported therein, and the treaty was eventually signed without reservations. ${ }^{51}$ The Note is significant not only because it reflects the consensus of fifteen powers of the time, but also because it qualifies the right of self-defence as 'inalienable, 'natural' and, for the first time, 'inherent', an adjective that would eventually find its way into article 51 of the UN Charter.

Article 3 of the 1933 Montevideo Convention on the Rights and Duties of States also reaffirmed the right of a state 'to defend its integrity and independence', a right which by virtue of article 5 is 'not susceptible of being affected in any manner. ${ }^{52}$ Neither the Nuremberg nor the Tokyo tribunals established at the end of the Second World War to prosecute the German and Japanese war criminals questioned in principle the existence of the plea of self-defence, although they rejected its invocation by the defendants. ${ }^{53}$ The Judgment of the International Military Tribunal for the Far East, in particular, went as far as to say that '[a]ny law, international or municipal, which prohibits recourse to force, is necessarily limited by the right of self-defence. ${ }^{54}$ The Draft Declaration on the Rights and Duties of States, adopted by the International Law Commission (ILC) in 1949, included self-defence in its article $12 .{ }^{55}$ In his Hague Academy Course on the rights and duties of states, Ricardo Alfaro, who drafted the ILC Declaration, identifies in selfpreservation one of four essential attributes inherent and inseparable from the notion of 'state' together with sovereignty, independence and equality. ${ }^{56}$ In his view, the difference between self-preservation and self-defence rests in the fact that the former is the

49 ILC, 'Preparatory Study Concerning a Draft Declaration on the Rights and Duties of States, Memorandum Submitted by the Secretary-General' (15 December 1948) UN Doc A/CN.4/2, 206.

50 Australia, Belgium, Canada, Czechoslovakia, France, Germany, Great Britain, India, the Irish Free State, Italy, Japan, New Zealand, Poland and South Africa.

51 Brownlie (n 22) 206-07.

52 Convention on the Rights and Duties of States adopted by the Seventh International Conference of American States (adopted 26 December 1933, entered into force 26 December 1934) 165 LNTS 19 (Montevideo Convention).

53 Ago (n 7) 60; Alexandrov (n 21) 75-76; Bowett (n 3) 140.

54 Judgment of the International Military Tribunal for the Far East (1948) 15 ILR 356, 364.

55 Draft Declaration on Rights and Duties of States with Commentaries, ILC YB 1949/IV, 288, art 12.

56 Ricardo J Alfaro, 'The Rights and Duties of States' (1959) 97 RdC 91, 98. 
abstract, objective, permanent right of the State to maintain and to develop itself within the international community' while the latter, which derives from self-preservation, is 'the concrete, subjective, eventual and transitory right of the State to use force in order to repel an attack against its integrity and its sovereignty. ${ }^{57}$

As has been seen, both the naturalistic and positivistic doctrines, at least until the beginning of the twentieth century, saw the right of states to defend themselves as a fundamental one. This fundamental character has found its way into modern codifications. The right of self-defence, for instance, is included in the list of 'fundamental rights and duties of states' contained in Chapter IV of the 1948 Charter of the Organization of American States. ${ }^{58}$ More famously, article 51 of the UN Charter qualifies it as 'inherent' and provides that nothing in the Charter can impair this right. The fundamental character of self-defence, however, never entailed that the right was an unfettered one. Necessity and 'moderation' were already emphasised as requirements of the defensive reaction by the classical scholars. Grotius maintained that ' $[\mathrm{w}]$ ar in defence of life is permissible only when the danger is immediate and certain, not when it is merely assumed"59 and only if the danger cannot be in any other way avoided. ${ }^{60}$ Suárez also argued that the 'natural and necessary' right of self-defence had to be exercised with moderation. ${ }^{61}$ Webster's letter to Fox in relation to the sinking of the Caroline claims that the extent of the right of self-defence

is a question to be judged of by the circumstances of each particular case, and when its alleged exercise has led to the commission of hostile acts within the territory of a Power at peace, nothing less than a clear and absolute necessity can afford ground for justification. ${ }^{62}$

He then famously subordinated a defensive use of force to 'a necessity of self-defence, instant, overwhelming, leaving no choice of means, and no moment for deliberation. ${ }^{63}$ In his view, self-defence allows 'nothing unreasonable or excessive; since the act, justified by the necessity of self-defence, must be limited by that necessity, and kept clearly within it. $^{\text {64 }}$

\section{The 'inherent right' of self-defence in article 51 of the UN Charter}

The right of self-defence is notoriously codified in article 51 of the UN Charter, which reads as follows:

57 ibid 102-03.

58 Charter of the Organization of American States (adopted 30 April 1948, entered into force 13 December 1951) 119 UNTS 48 (OAS Charter) art 22.

59 Grotius (n 16) book II, ch I, 173, para V.

60 ibid 175.

61 Suárez (n 15) Disputation XIII, 804, s I(6).

62 Letter from Daniel Webster (US Secretary of State) to Henry Fox (British Minister in Washington) (24 April 1841) (1857) 29 BFSP 1129, 1132-33.

63 ibid 1137-38.

64 ibid 1138 . 
Nothing in the present Charter shall impair the inherent right of individual or collective selfdefence if an armed attack occurs against a Member of the United Nations, until the Security Council has taken measures necessary to maintain international peace and security. Measures taken by Members in the exercise of this right of self-defence shall be immediately reported to the Security Council and shall not in any way affect the authority and responsibility of the Security Council under the present Charter to take at any time such action as it deems necessary in order to maintain or restore international peace and security.

The provision was included late in the negotiations, ie at the San Francisco conference, by the US delegation under pressure from the Latin American states ${ }^{65}$ without any debate on the meaning of 'inherent right' or the reasons for adding it. ${ }^{66}$ As previously seen, the expression finds its roots in the US Note in relation to the 1928 Pact of Paris. ${ }^{67}$ Some commentators maintain that, by including the word 'inherent', the drafters merely wanted to emphasise the fact that the right of self-defence was not created by the UN Charter and was therefore vested also in non-member states. ${ }^{68}$ Others see 'inherent' as a reference to the natural law right of self-defence. For instance, in his treatise on the law of the UN, Kelsen argues that article 51 of the UN Charter 'presupposes the existence of the right of self-defence as established, not by positive international law, but by natural law, for it speaks of an "inherent" right. ${ }^{69}$ For Kelsen, however, this reference to natural law has 'no legal importance. ${ }^{70}$ More recently, a commentator has also interpreted 'inherent'

65 In Dumbarton Oaks, it was believed that there would be no need to explicitly mention the right of selfdefence as this would be preserved anyway: self-defence issues, therefore, were not discussed on that occasion. See Murray Colin Alder, The Inherent Right of Self-Defence in International Law (Springer 2013) 86; Kinga Tibori Szabó, Anticipatory Action in Self-Defence (Asser Press 2011) 102.

66 There was also no discussion of the discrepancy between the English and French version during the drafting of art 51: Fletcher and Ohlin (n 9) 76.

67 The word 'inherent' also appears in the 1947 Inter-American Treaty of Reciprocal Assistance, art 3(1), in relation to the rights of individual and collective self-defence. See Inter-American Treaty of Reciprocal Assistance (adopted 2 September 1947, entered into force 3 December 1948) 21 UNTS 77 (Rio Treaty). OAS Charter, art 22, on the other hand, does not qualify the right as 'inherent'. The adjective 'inherent' is also used in human rights treaties. The 1996 UN Covenant on Civil and Political Rights, for instance, refers to the 'inherent right to life' of every human being (art 6(1)) and to the 'inherent right of all peoples to enjoy and utilize fully and freely their natural wealth and resources'. See Covenant on Civil and Political Rights (adopted 16 December 1966, entered into force 23 March 1976) 999 UNTS 171, art 47. The ICJ also considered the 'rights of the coastal State in respect of the area of continental shelf that constitutes a natural prolongation of its land territory into and under the sea' as 'inherent': North Sea Continental Shelf (Germany v Denmark; Germany v The Netherlands) (Merits) [1969] ICJ Rep 3 (North Sea Continental Shelf) para 19.

68 Stefaan Smis and Kim Van der Borght, 'The Advisory Opinion on the Legality of the Threat or Use of Nuclear Weapons' (1998-99) 27 Georgia J Intl \& Comp L 345, 368; Leland M Goodrich and Edvard Hambro, The Charter of the United Nations (Columbia UP 1969) 344; Bowett (n 3) 187. See the US legal position in relation to the US intervention in collective self-defence of South Vietnam: Department of State, 'The Legality of the United States Participation in the Defense of Vietnam' in Richard Falk (ed), The Vietnam War and International Law (Princeton UP 1968) 583ff.

69 Hans Kelsen, The Law of the United Nations: A Critical Analysis of its Fundamental Problems (Stevens 1950) 791.

70 ibid 791-92. See also Randelzhofer and Nolte (n 1) 1403: 'Too great a relevance must not be attached to the designation as "inherent", for instance by holding that art 51 refers in a declaratory manner to a right of self-defence existing independently from the Charter under natural law.' 
as referring to the natural law conception of the right of self-defence but, unlike Kelsen, has seen this as an explicit incorporation of that right into the UN Charter: 'natural law becomes positive law once it is incorporated into the written provisions of the treaty, although to fix the content of its exact source one needs to consult natural law as an interpretative guide to what the provision means. ${ }^{71}$ In Nicaragua, the International Court of Justice (ICJ) famously interpreted 'inherent' not as a reference to natural law but to customary international law without entirely clarifying whether the reference is in fact a renvoi. ${ }^{72}$ Koskenniemi points out, 'In view of the fact that the Court made no reference to State practice or the opinio juris on this point it can only be concluded that its "custom" was in fact no different from a naturalistic principle. ${ }^{73}$ Be that as it may, the ICJ's interpretation of 'inherent' as 'customary' does not find support in the letter of article 51 of the UN Charter: a customary right is not 'inherent', as it comes into existence only when the two elements of custom have sedimented. Furthermore, none of the expressions used in the authentic texts of this provision ('inherent right' (English), 'droit naturel' (French), 'derecho inmanente' (Spanish), 'неотъемлемого права' (Russian), ‘自然' (Chinese, in pinyin written ziran) and 'بئبط' (Arabic)) is normally used in their respective languages to refer to customary law, and a special meaning can be given to the terms of a treaty only 'if it is established that the parties so intended. ${ }^{74}$ There is no evidence of this intention in the travaux préparatoires of the UN Charter.

To properly understand the meaning of 'inherent', one needs to apply the rules on treaty interpretation contained in articles 31-33 of the 1969 Vienna Convention on the Law of Treaties (VCLT). Even though the Convention does not apply to treaties concluded before its entry into force, ${ }^{75}$ the rules on interpretation contained therein are generally considered a codification of pre-existing customary international law and are therefore also applicable to the UN Charter. ${ }^{76}$ Article 31 of the VCLT identifies three primary interpretive criteria: 'A treaty shall be interpreted in good faith in accordance with the ordinary meaning to be given to the terms of the treaty in their context and in the light of its object and purpose.' The contextual approach is not useful to interpret 'inherent' in article 51 of the UN Charter: this word does not appear elsewhere in the UN Charter or in agreements and other instruments related to it. ${ }^{77}$ The ordinary meaning of 'inherent' is, according to the Oxford English Dictionary, 'existing in something as a

71 Jens D Ohlin, 'The Doctrine of Legitimate Defense' (2015) 91 Intl L Studies 119, 126 (emphasis in the original).

72 Military and Paramilitary Activities in and against Nicaragua (Nicaragua $v$ US) (Merits) [1986] ICJ Rep 14 (Nicaragua) para 176: 'The Court (...) finds that Article 51 of the Charter is only meaningful on the basis that there is a "natural" or "inherent" right of self-defence, and it is hard to see how this can be other than of a customary nature, even if its present content has been confirmed and influenced by the Charter.'

73 Martii Koskenniemi, From Apology to Utopia: The Structure of International Legal Argument (CUP 2005) 405.

74 Vienna Convention on the Law of Treaties (adopted 23 May 1969, entered into force 27 January 1980) 1155 UNTS 332 (VCLT) art 31(4).

75 ibid art 4.

76 Stefan Kadelbach, 'The Interpretation of the Charter' in Bruno Simma and others (eds), The Charter of the United Nations-A Commentary, vol 1 (3rd edn, OUP 2012) 75.

77 VCLT, art 31(2). 
permanent or essential attribute. ${ }^{78}$ Black's Law Dictionary sees 'inherent' as synonymous with 'inalienable', which is '[a] right that cannot be transferred or surrendered; esp., a natural right such as the right to own property. ${ }^{79}$

If one looks at the other authentic texts of article 51 of the UN Charter, both the French and the Chinese versions refer to the 'natural' right of self-defence ('droit naturel', 自然). 'Droits naturels' in the French language are defined as 'droits innés et inaliénables que chaque individu possède par naissance et nature sans avoir besoin de les tenir d'un acte ni pouvoir les aliéner et dont les gouvernants sont tenus d'assurer le respect. ${ }^{80} \mathrm{~A}$ 'droit naturel', therefore, is inherent, inalienable and inviolable. The Spanish version of article 51 of the UN Charter refers to self-defence as a 'derecho inmanente' ('inherent'), ${ }^{81}$ and the Russian expression 'неотъемлемого права' literally translates into English as 'inalienable' right. ${ }^{82}$ Finally, the Arabic version of article 51 of the UN Charter employs 'بيعي', which means not only 'natural' but also 'inherent', a necessary and logical consequence of something. ${ }^{83}$

The above considerations suggest that, in article 51, 'inherent' means that 1) the right of self-defence pre-existed the UN Charter; 2) it belongs to any state, whether or not it is a member of the UN; and 3) no UN Charter provisions can deprive a state of it. This is the interpretation that best reconciles the ordinary meaning of the different adjectives used in the authentic texts of article 51 of the UN Charter. ${ }^{84}$ As Ago explains,

the word 'inherent' (...) is intended primarily to emphasize that the ability to make an exception to the prohibition on the use of force for the purpose of lawfully defending itself against an armed attack is a prerogative of every sovereign State and one that it is not entitled to renounce. This signifies (...) that no treaty can 'derogate' from this prerogative manifestly vested in States by an imperative principle. ${ }^{85}$

In his testimony before the Committee on Foreign Affairs, John Foster Dulles also pointed out that in San Francisco

There was no attempt to limit the inherent right of self-defense. (...) I pointed out that there was that inherent right that could not be taken away by implication or even in my opinion expressly, because no individual can give up the right to protect his own life. ${ }^{86}$

78 Catherine Soanes (ed), The Compact Oxford English Dictionary (2nd edn, OUP 2003) 574.

79 Bryan A Garner (ed), Black's Law Dictionary (10th edn, Thomson Reuters 2014) 1518.

80 Gérard Cornu (ed), Vocabulaire Juridique (PUF 2014) 677-78.

81 The New Velázquez Spanish and English Dictionary (Velázquez Press 2003) pt I, 540.

82 Oxford Russian Dictionary (3rd edn, OUP 2000) 258.

83 Rohi Baalbaki, Al-Mawrid Arabic-English Dictionary (7th edn, Dar El-Ilm Lilmalayin 1995) 722.

84 See VCLT, art 33(4): 'Except where a particular text prevails in accordance with paragraph 1, when a comparison of the authentic texts discloses a difference of meaning which the application of articles 31 and 32 does not remove, the meaning which best reconciles the texts, having regard to the object and purpose of the treaty, shall be adopted.'

85 Ago (n 7) 67.

86 Structure of the United Nations and Relations of the United States to the United Nations: Hearings before the House Committee on Foreign Affairs, 80th Congress, 2nd Session (1948) 298. 
But 'inherent' in what? Like non-intervention/non-interference, ${ }^{87}$ self-defence is an example of what Serge Sur has called in a recent article 'functional inherences' (inhérences fonctionelles), ie those which are necessary for the very existence of a state and to the exercise of its competences. ${ }^{88}$ Indeed, it is difficult to see how a state could be really independent if it does not possess the right to defend such independence. The requirement of a defined territory as an element of statehood also implies the right to defend sovereignty over that territory. To paraphrase Ago, it is the rightful holder of the subjective right to territorial sovereignty and political independence 'who is at the same time given the faculty of taking measures for the purpose of safeguarding the right in question. ${ }^{89}$ Legal inherence has nothing to do with natural law: ${ }^{90}$ on the contrary, 'elle est un accompagnement necessaire du droit positif. ${ }^{11}$ As the defence counsel at Nuremberg argued, 'War in self-defence is permitted as an inalienable right to all states; without that right, sovereignty does not exist.' ${ }^{92}$ In his Dissenting Opinion attached to the Nuclear Weapons Advisory Opinion, Judge Shahabuddeen also recalls that '[s]ince the right of self-defence is "inherent" in a State, it is not possible to conceive of statehood which lacks that characteristic.. ${ }^{93}$ Judge Fleischhauer's Separate Opinion concurs and affirms that 'the inherent right of self-defence' is a right 'which every State possesses as a matter of sovereign equality. ${ }^{94}$ These views find support in the ILC's choice to adopt a Declaration on rights and duties of states, and not a convention, as 'the rights and duties

87 Niki Aloupi, 'The Right to Non-intervention and Non-interference' (2015) 4 CJICL 566.

88 Serge Sur, 'L'inhérence en droit international' (2014) 118 Revue Générale de Droit International Public 790, 791-92. For this author, 'La réunion des critères requis pour la naissance d'un Etat entraîne (...) des conséquences inhérentes à cette situation' (ibid 789); 'inhérences étatiques', 'inhérences fonctionnelles' and 'inhérences structurelles' (ibid 787-89, 790-92, 794-95, respectively). See also Lamberti Zanardi (n 21) 214. The Declaration on Friendly Relations emphasises that the principle of sovereign equality of states entails that '[e]ach State enjoys the rights inherent in full sovereignty' (Declaration on Principles of International Law concerning Friendly Relations and Co-operation among States in accordance with the Charter of the United Nations, UNGA Res 2625 (XXV) (24 October 1970) UN Doc A/RES/25/2625). Some commentators have argued that the right of self-defence, like all other fundamental rights, is inherent not only in statehood or state sovereignty, but also in the international legal order itself and is necessary for the proper functioning of the system: d'Aspremont, 'The Doctrine of Fundamental Rights of States and Anthropomorphic Thinking in International Law' (n 9) 501 (referring to scholars of the 'golden age' of the doctrine of fundamental rights of states, ie 1850-1945); Sergio M Carbone and Lorenzo Schiano di Pepe, 'States, Fundamental Rights of' in Max Planck Encyclopedia of Public International Law, vol 30 (OUP 2012) para 36. It is worth recalling that in the Gulf of Maine judgment, the ICJ identified a 'limited set of [customary] norms for ensuring the co-existence and vital co-operation of the members of the international community': Delimitation of the Maritime Boundary in the Gulf of Maine Area (Canada $v$ United States) (Merits) [1984] ICJ Rep 246, para 111.

89 Ago (n 7) 56.

90 Sur (n 88) 786.

91 ibid 797. In North Sea Continental Shelf (n 67) para 38, for instance, the ICJ found that if it is correct that the equidistance principle is (...) to be regarded as inherent in the whole basic concept of continental shelf rights, then equidistance should constitute the rule according to positive law tests also'.

92 Cited in Bowett (n 3) 140: the Prosecutor for the United Kingdom did not contest this point and referred to self-defence as a 'natural right'. The disagreement between prosecution and defence was rather on who is to be the judge that the circumstances of self-defence exist.

93 Nuclear Weapons (n 5) 417 (Judge Shahabuddeen).

94 ibid 305 (Judge Fleischhauer). 
of States as such are not created by the text of a treaty or international Convention but are inherent in their quality as States and can only be recognized or stated.95

To be clear, self-defence is a consequence of statehood, and not one of its constitutive elements (which are instead identified in article 1 of the Montevideo Convention): in fact, it is an essential means to defend the constitutive elements. Also, the fact that selfdefence is inherent in statehood does not mean that it is an absolute right. ${ }^{96}$ Rivier points out that 'l'aliénation complète et définitive d'un [des droits essentiels] serait incompatible avec le maintien de la qualité d'État souverain, personne complète du droit des gens, pair des autres États'. However, 'rien n'empêche qu'un État puisse renoncer pour un temps, même indéfini, dans des circonstances données et en faveur d'un ou de plusieurs autres États, à certaines manifestations d'un droit essential, et en suspendre à certains égards l'exercise. .97 In other words, 'Self-defence is an inherent right, but one which is subject to legal considerations and the violation of one or more of those considerations can divest the state of its right to continue to exercise it. ${ }^{98}$ It is through these lenses that one should read article 51 of the UN Charter, which does not 'impair' the inherent right of selfdefence (and could have not done so), but submits its exercise to certain conditions and requirements in order to adjust it to the collective security system established by the UN Charter. ${ }^{99}$ However, no requirement imposed on the exercise of the right of self-defence could lead to completely deprive a state of the right itself.

It should be noted that, in contrast with the above mentioned classical doctrine that saw self-defence not only as a fundamental right of states but also as a duty, there is no basis for such a duty in article 51 of the UN Charter or customary international law. ${ }^{100}$ States may be under a duty to react to neutrality violations under the law of neutrality or a treaty on permanent neutrality, or under a duty to react against armed attacks as provided in mutual defence treaties. ${ }^{101}$ Such a duty, however, would be based not on article 51 of the UN Charter or its customary counterpart, but on the law of neutrality, the permanent neutrality treaty or the mutual defence treaty. Outside these situations, a state 'has the right to commit suicide. ${ }^{102}$ Still, the naturalistic notion of self-defence as a duty that a state owes to itself or to its own population has not completely disappeared as a legal narrative. It suffices to remember the ICJ's words in the 2004 Palestinian Wall

95 ILC, 'Preparatory Study Concerning a Draft Declaration on the Rights and Duties of States, Memorandum Submitted by the Secretary-General' (15 December 1948) UN Doc A/CN.4/2, 213.

96 This notion is criticised by Alfaro (n 56) 113-14.

97 Rivier (n 31) 258.

98 Terry D Gill, 'When Does Self-Defence End?' in Marc Weller (ed), The Oxford Handbook on the Use of Force (OUP 2015) 746.

99 In particular, it requires that all measures taken in self-defence be reported to the UN Security Council and that measures in self-defence may be taken only until the Council 'has taken the measures necessary to maintain international peace and security' (see below section 6). Whether or not the reference to an ongoing 'armed attack' is a further conditionality imposed by the UN Charter, art 51, on the exercise of the inherent right of self-defence is controversial and is outside the scope of this article.

100 Brownlie (n 22) 262.

101 Dinstein (n 1) 191; Brownlie (n 22) 262.

102 Florence Poirat, 'La doctrine des droits fondamentaux de l'Etat' (1992) 16 Droits Revue Française de Théorie Juridique 83, 91. 
Advisory Opinion: 'The fact remains that Israel has to face numerous indiscriminate and deadly acts of violence against its civilian population. It has the right, and indeed the $d u t y$, to respond in order to protect the life of its citizens.' ${ }^{\text {'103 }}$

One final observation concerns the right of collective self-defence. While article 51 of the UN Charter does not distinguish between individual and collective self-defence and qualifies both as inherent, this is difficult to justify in relation to the latter. Indeed, it does not seem to be a right without which sovereignty cannot exist or an essential means through which to defend the constitutive elements of statehood. The right of the victim state to ask for help may well be inherent, but the 'right' of other states to come to its assistance is not: in fact, as will be seen, permanent neutral states have renounced this right. ${ }^{104}$ Collective self-defence is not even a right: as the ICJ explained in Nicaragua, it is subordinated to the request of the victim state. ${ }^{105}$

If the addition of 'inherent' in relation to self-defence is a reminder by the UN Charter drafters that such right is a corollary of statehood, then it remains to be seen what legal consequences, if any, such characteristic entails. This will be explored in the next sections.

\section{The inalienable character of self-defence}

One of the consequences of the inherent character of the right of self-defence is its inalienability; as Ago puts it, the right of self-defence is a prerogative that a state is not entitled to renounce. ${ }^{106}$ This is not contradicted by the status of permanent neutrality that characterises certain states, namely Switzerland and Austria. ${ }^{107}$ Such status is normally based on a multilateral or, more rarely, a bilateral treaty and entails an obligation on the state in question not to be involved in armed conflict and not to participate in acts that may lead to that result, for instance participation in military alliances, acceptance of foreign military bases or the passage of foreign troops on its territory. Permanent neutrality, however, never excludes the right of the state to use force in self-defence. ${ }^{108}$ As the delegate of the Serb-Croat-Slovene state declared on 12 January 1920 to oppose a proposal for demilitarisation of certain parts of the Yugoslav territory, 'Even the international conventions, which provided for neutralisation (concerning Belgium and Switzerland, for instance), preserved intact the right of neutral countries to defend their

103 Legal Consequences of the Construction of a Wall in the Occupied Palestinian Territory (Advisory Opinion) [2004] ICJ Rep 136 (Palestinian Wall) para 142 (emphasis added). For this view in the literature, see Rosenne (n 5) 59.

104 It has been observed that '[p] ermanent neutrality means a renunciation of the right of collective selfdefence, ie the right to grant assistance, but not a renunciation of the right to accept help from others if the permanently neutral State is itself attacked': Michael Bothe, 'Neutrality, Concept and General Rules' in Max Planck Encyclopedia of Public International Law, vol 7 (OUP 2012) 621.

105 Nicaragua (n 72) para 198.

106 Ago (n 7) 67, fn 263.

107 Natalino Ronzitti, Diritto Internazionale dei Conflitti Armati (4th edn, Giappichelli 2011) 114-15.

108 Josef L Kunz, 'Austria’s Permanent Neutrality' (1956) 50 AJIL 418, 419. 
frontiers by force of arms. ${ }^{109}$ The judgment in the High Command trial also found that a permanently neutral state like Switzerland might use 'her military strength to implement a national policy that seeks peace and to maintain her borders against aggression.' ${ }^{110}$ In fact, permanently neutral states normally have not only a right, but also a duty to defend their neutrality. ${ }^{111}$

Apart from permanent neutrality, even 'peace constitutions' ${ }^{112}$ like those of Germany and Japan do not rule out the use of the armed forces in self-defence. While article 9 of the Japanese Constitution provides that the Japanese people forever renounce war as a sovereign right of the nation and the threat or use of force as means of settling international disputes', Japan possesses Ground, Maritime and Air Self-Defence Forces. ${ }^{113}$ Article 26(1) of Germany's Basic Law provides that '[a]cts tending to and undertaken with intent to disturb the peaceful relations between nations, especially to prepare for a war of aggression, shall be unconstitutional'. Article 87(a)(1) of Germany's Basic Law, however, allows the establishment of armed forces for the purposes of defence. ${ }^{114}$ Article 2 of the 1990 Treaty on the Final Settlement with Respect to Germany also states that 'the united Germany will never employ any of its weapons except in accordance with its constitution and the Charter of the United Nations', therefore excluding self-defence actions, and the right of Germany to participate in defensive alliances is expressly reaffirmed in article $6 .{ }^{115}$

There are also several present-day examples of states that have entirely entrusted their defence to other states. According to the 2002 Treaty intended to adapt and strengthen friendship and cooperation relations between the Principality of Monaco and the French Republic, for example, the French Republic is responsible for the military defence of the Principality. ${ }^{116}$ The Constitutions of Niue and the Cook Islands (1974 and

109 Documents on British Foreign Policy, 1919-1939 (First Series, vol 2, no 67, HMSO 1948) 821.

110 In re von Leeb et al (1948) 15 ILR 376, 381.

111 Kunz (n 108) 424.

112 Russell A Miller, 'Germany's Basic Law and the Use of Force' (2010) 17 Intl J Global L Studies 197, 199.

113 Japanese Self-Defence Forces Act, Act No 165 of 1954.

114 With the 1945 Berlin Declaration, the four Allied Powers assumed 'supreme authority with respect to Germany' and demilitarised the country: Katarina Weilert, 'Germany, Legal Status After World War II' in Max Planck Encyclopedia of Public International Law (online edition) para $5<$ http://opil.ouplaw.com/ home/EPIL> accessed 5 July 2015. In that period, it was doubtful that Germany was still a fully sovereign state (ibid para 16). The 1952 Convention on Relations between the Three Powers and the Federal Republic of Germany (adopted 26 May 1952, entered into force 5 May 1955) 331 UNTS 327, as amended by the 1954 Protocol on the Termination of the Occupation Regime in the Federal Republic of Germany (adopted 23 October 1954, entered into force 5 May 1955) 331 UNTS 253, art 1(2) restored to the formerly occupied state 'the full authority of a sovereign State over its internal and external affairs'. See also the Treaty Concerning Relations Between the Union of the Soviet Socialist Republics and the German Democratic Republic (adopted 20 September 1955, entered into force 6 October 1955) 226 UNTS 201.

115 Treaty on the Final Settlement with Respect to Germany (adopted 12 September 1990, entered into force 15 March 1991) 1696 UNTS 124.

116 Treaty Intended to Adapt and Strengthen Friendship and Cooperation Relations between the Principality of Monaco and the French Republic (adopted 24 October 2002) Ordinance no 407 of 15 February 2006, art 1 <http://www.legimonaco.mc/305/legismclois.nsf/db3b0488a44ebcf9c12574c7002a8e84/d1db400f ecb1721bc125773f003d3fbb! OpenDocument\&Highlight=0,407> accessed 5 July 2015: 'La République française assure à la Principauté de Monaco la défense de son indépendance et de sa souveraineté et 
1965, respectively) provide that New Zealand retains responsibility for the defence of the two states. Title three, article 1, section 311 of the Compacts of Free Association between the Federated States of Micronesia and the United States and between the Republic of the Marshall Islands and the United States also provides that ' $[\mathrm{t}]$ he Government of the United States has full authority and responsibility for security and defense matters in or relating to' the Federated States of Micronesia and the Republic of the Marshall Islands, which includes 'the obligation to defend the Federated States of Micronesia [and of the Republic of the Marshall Islands] and [their] people from attack or threats thereof as the United States and its citizens are defended.' ${ }^{17}$ Similarly, article 1, section 312 of the Compact of Free Association between Palau and the United States provides that the latter 'has full authority and responsibility for security and defense matters in or relating to Palau.' ${ }^{\prime 18}$ Section 313 of the Compacts with Palau, Micronesia and Marshall Islands adds that the governments of the three states 'shall refrain from actions which the Government of the United States determines, after consultation with that Government, to be incompatible with its authority and responsibility for security and defense matters in or relating to' those states.

The statehood of the above entities is generally not contested. Does this mean that a state can alienate its right of self-defence to another state without losing its statehood? This would seem to be inconsistent with the inherent character of the right of selfdefence as described above. Again, one should not lose sight of the distinction between the right itself and the exercise of the right. In the above cases, states have not alienated their right of self-defence, but merely delegated its exercise to another state. The Pacific People's Constitution Report adopted by the New Zealand government in 2000 expressly states that ' $[w]$ here the New Zealand Government exercises responsibilities in respect of external affairs and defence, it does so in effect on the delegated authority of the Government of Niue. ${ }^{119}$ It is implicit in the notion of delegation (as opposed to that of alienation) that the delegated powers can be revoked. Furthermore, if the state

garantit l'intégrité du territoire monégasque dans les mêmes conditions que le sien'. See also Treaty on the Relations between the Principality and France (adopted 17 July 1918) Ordinance of 14 November 1920, art 1 <http://www.legimonaco.mc/305/legismclois.nsf/db3b0488a44ebcf9c12574c7002a8e84/cf98c1484c 39d9eac125773f003778d0! OpenDocument\&Highlight=0,1919> accessed 5 July 2015: 'Le gouvernement de la République française assure à la Principauté de Monaco la défense de son indépendance et de sa souveraineté et garantit l'intégrité de son territoire comme si ce territoire faisait partie de la France'. See also Peace Treaty of Versailles (adopted 28 June 1919, entered into force 10 January 1920) 13 AJIL Supp 151, 385 (1919) art 436: 'The High Contracting Parties declare and place on record that they have taken note of the Treaty signed by the Government of the French Republic on July 17, 1918, with His Serene Highness the Prince of Monaco defining the relations between France and the Principality.'

117 Compacts of Free Association Act of 1985 between the Federated States of Micronesia and the United States and between the Republic of the Marshall Islands and the United States, Public Law 99-239, as amended by the Compacts of Free Association Act of 2003, Public Law 108-188. The provisions specify that ' $\mathrm{t}$ ] he Government of the United States confirms that it shall act in accordance with the principles of international law and the Charter of the United Nations in the exercise of this authority and responsibility?.

118 Compact of Free Association Act of 1994 between Palau and the United States, Public Law 99-658.

119 New Zealand Ministry of Justice and Ministry of Pacific Islands Affairs of New Zealand, 'Pacific People's Constitution Report' (2000) 33, s 3.2 <http://www.justice.govt.nz/publications/publications-archived/2000/ pacific-peoples-constitution-report-september-2000> accessed 5 July 2015. 
responsible for the defence of another state does not adequately do so, the latter state could adopt defensive measures with the means at its disposal.

\section{Does self-defence take precedence over other international law?}

The question that this section addresses is whether the inherent character of self-defence makes it supersede any other conflicting obligations incumbent on the state victim of an armed attack. ${ }^{120}$ In some cases, the prevalence is expressly stated. The 2013 Arms Trade Treaty, for instance, reaffirms the 'inherent right of all States to individual or collective self-defence as recognized in Article 51 of the Charter of the United Nations' and ' $\mathrm{t}$ ] he respect for the legitimate interests of States to acquire conventional arms to exercise their right to self-defence and for peacekeeping operations; and to produce, export, import and transfer conventional arms. ${ }^{121}$ In other cases, the prevalence has been considered implicit: in the Nuclear Weapons Advisory Opinion, the ICJ did not find that environmental treaties could be interpreted as depriving states of their right of self-defence. $^{122}$

As the ILC Commentary to article 21 of its Articles on the Responsibility of States for Internationally Wrongful Acts observes, however, self-defence does not preclude the wrongfulness of conduct 'in all cases or with respect to all obligations. ${ }^{123}$ The ILC notes that, although the inherent right to self-defence may justify non-performance of certain treaties, this does not apply to 'obligations under international humanitarian law and in relation to non-derogable human rights provisions. ${ }^{124}$ In the Nuclear Weapons Advisory Opinion, the ICJ distinguished between obligations of 'total restraint during military conflict', which may 'deprive a State of the exercise of its right of self-defence, ${ }^{125}$ and other obligations. The ICJ was ambiguous on the relationship between the jus ad bellum

120 The problem can be seen either as a conflict between primary norms or as the application of a secondary rule precluding the wrongfulness of the violation of a primary rule (on the distinction between primary and secondary rules, see HLA Hart, The Concept of Law (2nd edn, OUP 1994) 94ff). If the latter, it should be noted that self-defence can work not only as a circumstance that precludes the wrongfulness of an otherwise unlawful use of force, but also of other violations of international law: Lamberti Zanardi (n 21) 129; Bowett (n 3) 270. This view finds support in the ICJ Advisory Opinion on the Palestinian Wall (n 103) para 139, where the Court considered the self-defence argument advanced by Israel to justify the construction of the security fence. The argument was eventually not accepted because, according to the Court, the conditions for self-defence, in particular the fact that the armed attack must come from another state, had not been met.

121 Arms Trade Treaty (adopted 2 April 2013, entered into force 24 December 2014) UNGA Res 67/234B, preamble.

122 Nuclear Weapons (n 5) para 30.

123 ILC, Responsibility of States for Internationally Wrongful Acts-Commentary, ILC YB 2001/II(2) 74, art 21. It should be recalled that self-defence cannot preclude the wrongfulness of any act of a State which is not in conformity with an obligation arising under a peremptory norm of general international law' (ILC Articles on State Responsibility, art 26).

124 ILC, Responsibility of States for Internationally Wrongful Acts-Commentary (n 123) 74.

125 Nuclear Weapons (n 5) para 30. As mentioned, the ICJ concluded that environmental treaties did not belong to this category. 
right of self-defence and the obligations of states in the conduct of hostilities under the jus in bello: despite concluding that the use of nuclear weapons is 'generally contrary' to the law of armed conflict, it did not rule out that the use of nuclear weapons could be lawful 'in an extreme circumstance of self-defence, in which the very survival of a State would be at stake. ${ }^{126}$

In Judge Fleischhauer's view, the inherent right of self-defence trumps the limitations imposed on the use of weapons under the jus in bello when negating the use of a prohibited weapon would equate to depriving a state of its right of self-defence. ${ }^{127}$ In his view, neither 'principle' (the law of armed conflict and the inherent right of selfdefence) prevails as they have equal rank, ${ }^{128}$ and the conflict must be settled by finding 'the smallest common denominator between the conflicting principles', ie by allowing the use of nuclear weapons exclusively when it is the means of last resort against an armed attack that threatens the very existence of the victim state. ${ }^{129}$

These views are rightly criticised by Judge Weeramantry, who passionately maintains that 'the undoubted right of the State that is attacked to use all the weaponry available to it for the purpose of repulsing the aggressor (...) holds only so long as such weapons do not violate the fundamental rules of warfare embodied in those rules. ${ }^{130}$ A different conclusion would undermine the distinction between the jus ad bellum and the jus in bello: 'while the jus ad bellum only opens the door to the use of force (in self-defence or by the Security Council), whoever enters that door must function subject to the jus in bello.'.131 Judge Shahabuddeen concurs and emphasises that 'it is necessary to distinguish between the inherent right of self-defence and the means by which the right is exercisable': the latter falls under the scope of the jus in bello. ${ }^{132}$ Similarly, President Bedjaoui affirms that, in spite of the 'fundamental' character of the right of a state to survival, this right

ne peut engendrer une situation dans laquelle un Etat s'exonérait lui-même du respect des norms 'intransgressibles' du droit international humanitaire. (...) On manquerait par conséquent de la plus élémentaire prudence si on plaçait sans hésitation la survie d'un Etat au-dessus de toutes autres considérations, et en particulier au-dessus de la survie de l'humanité elle-même. ${ }^{133}$

\footnotetext{
126 ibid para $105(\mathrm{E})$.

127 ibid 307 (Judge Fleischhauer): 'the denial of the recourse to the threat or use of nuclear weapons as a legal option in any circumstance could amount to a denial of self-defence itself if such recourse was the last available means by way of which the victimized State could exercise its right under Article 51 of the Charter'.

128 ibid 306, 308 (Judge Fleischhauer).

129 ibid 308 (Judge Fleischhauer). His opinion recalls the remarks of US Secretary of State Dean Acheson at the 1963 Conference of the American Society of International Law: 'law does simply not deal with such questions of ultimate power-power that comes close to the sources of sovereignty. (...) The survival of states is not a matter of law'. See Dean Acheson, 'Law and Conflict: Changing Patterns and Contemporary Challenges-Panel: Cuban Quarantine: Implications for the Future: Remarks' (1963) 57 ASIL Proc 14.

130 Nuclear Weapons (n 5) 514 (Judge Weeramantry) (emphasis in the original).

131 ibid 519.

132 ibid 418 (Judge Shahabuddeen).

133 ibid para 22 (President Bedjaoui).
} 
Means and methods of warfare prohibited under the law of armed conflict, therefore, may never be used, not even in self-defence. ${ }^{134}$ This conclusion finds support in the Draft Articles on the effects of armed conflicts on treaties, adopted by the ILC in 2011. ${ }^{135}$ The pre-eminence of self-defence over other treaty regimes is stated by draft article 14, according to which

A state exercising its inherent right of individual and collective self-defence in accordance with the Charter of the United Nations is entitled to suspend in whole or in part the operation of a treaty to which it is a Party insofar as that operation is incompatible with the exercise of that right.

The right of self-defence, therefore, prevails over other treaty obligations owed by the victim state not only towards the aggressor but also towards other states. According to the Commentary, however, this prevalence does not affect treaties designed to apply in armed conflict, in particular the law of armed conflict. ${ }^{136}$

The exercise of self-defence may also be affected by mechanisms to peacefully settle international disputes. The question has arisen, for instance, of whether a state may resort to self-defence pendente lite, in particular after the dispute has been submitted to the ICJ. This is not a real case of conflicting obligations: if the dispute has been submitted to a judicial mechanism, the defensive reaction will normally not be necessary. If the aggressor resumes hostilities, however, the right of self-defence may be exercised again. ${ }^{137}$ It is worth recalling that, in obiter dictum, the Tehran Hostages judgment stated that the operation carried out by the United States 'in exercise of its inherent right of self-defence with the aim of extricating American nationals who have been and remain the victims of the Iranian armed attack on Our Embassy' ${ }^{\text {'38 }}$ may have undermined 'respect for the judicial process in international relations. ${ }^{139}$

\section{Self-defence and the UN Security Council's powers}

To what extent, if any, may the UN Security Council limit the 'inherent right' of selfdefence of states? The UN Security Council's primacy in the maintenance of international peace and security is affirmed three times in article 51 of the UN Charter. First, states have a duty to report to the Council any measures taken in self-defence. Non-compliance with this requirement does not affect the legality of an otherwise lawful exercise of selfdefence. As highlighted by Judge Schwebel in his Dissenting Opinion in Nicaragua, '[a] State cannot be deprived, and cannot deprive itself, of its inherent right of individual or

\footnotetext{
134 Judith Gardam, Necessity, Proportionality and the Use of Force by States (CUP 2004) 169.

135 Draft Articles on the Effects of Armed Conflicts on Treaties with Commentaries, ILC YB 2011/II(2).

Customary international law is not mentioned because it is outside the scope of the Draft Articles.

136 ibid.

137 Dinstein (n 1) 236.

138 US Diplomatic and Consular Staff in Tehran (United States v Iran) (Merits) [1980] ICJ Rep 3, para 32.

139 ibid para 93.
} 
collective self-defence because of its failure to report measures taken in the exercise of that right to the Security Council. ${ }^{140}$

Furthermore, the second sentence of article 51 of the UN Charter provides that self-defence measures 'shall not in any way affect the authority and responsibility of the Security Council (...) to take at any time such action as it deems necessary in order to maintain or restore international peace and security'. The only meaning that this clause could have is that the UN Security Council may take over from states at any time. Therefore, even if states have already reacted, or are reacting, in individual or collective self-defence, they are under an obligation not to impair the Council's action.

The same point appears in clearer terms in the first sentence of article 51 of the UN Charter, which provides that states may exercise the individual or collective right of selfdefence only 'until the Security Council has taken the measures necessary to maintain international peace and security. ${ }^{141}$ This does not entail, as Schachter argues, that the inherent right of self-defence can be taken away from states if and when the Security Council adopts such measures. ${ }^{142}$ It is its exercise that may be suspended because, like in domestic legal systems, it becomes unnecessary when a public authority takes charge of the protection of the community members. As Neff puts it, 'The more prompt and effective the UN Security [Council] was, the smaller a part would self-defence naturally play. $^{\text {'143 }}$

As the travaux préparatoires of the UN Charter confirm, ${ }^{144}$ not every measure adopted by the Security Council is able to suspend the exercise of the right of selfdefence by states, but only those that are adequate to effectively maintain international peace and security. ${ }^{145}$ It is only in this case that the exercise of self-defence by states becomes unnecessary. As the Egyptian delegate to the UN emphasised in 1954,

the individual or collective right of self-defence may not be over-ridden in favour of the Security Council except insofar as the States concerned are so well protected by the resources available to the Security Council that the abandonment of their right of self-defence will not harm them. ${ }^{146}$

140 Nicaragua (n 72) para 230 (Judge Schwebel).

141 See also Rio Treaty, art 3(4).

142 Oscar Schachter, International Law in Theory and Practice (Nijhoff 1991) 403. See also Kelsen, The Law of the United Nations (n 69) 797.

143 Neff, War and the Law of Nations (n 22) 327.

144 Malvina Halberstam, 'The Right to Self-Defense Once the Security Council Takes Action' (1995-96) 17 Michigan J Intl L 229, 240ff; Terry D Gill, 'Legal and Some Political Limitations on the Power of the UN Security Council to Exercise its Enforcement Powers under Chapter VII of the Charter' (1995) 26 NYIL $33,97$.

145 Jutta Brunnée, 'The Security Council and Self-Defence: Which Way to Global Security?' in Niels Blokker and Nico Schrijver (eds), The Security Council and the Use of Force: Theory and Reality (Nijhoff 2005) 128; Halberstam (n 144) 240-41. The legislative history of art 51 of the UN Charter reveals that the inclusion of the verb 'to restore' was deemed unnecessary, as it would be encompassed by 'to maintain'. See Carin Kaghan, 'Jus Cogens and the Inherent Right to Self-Defense' (1996-97) 3 J Intl \& Comp L 767, 821-22.

146 UNSC Verbatim Record (5 February 1954) UN Doc S/PV.658. 
The ILC has also stressed that self-defence is allowed 'where (...) the use of force by the agencies of the central authority cannot be resorted to promptly and efficiently enough to protect a subject against an attack by another. ${ }^{147}$ In contrast with what is argued by a leading commentator, ${ }^{148}$ it is not the type of measure adopted by the UN Security Council that makes the difference. In particular, it is not necessary that the Security Council replaces the right of self-defence 'with its functional equivalent, that is, collective intervention on behalf of the aggrieved state. ${ }^{149}$ What counts for the purposes of suspending the exercise of the right of self-defence by states is that, whatever measures the UN Security Council adopts, it is effective in maintaining international peace and security, which necessarily involves a case-by-case evaluation. ${ }^{150}$ The prevalent view is that 'it is not for the state allegedly taking action in self-defence to decide whether the Security Council has taken the measures necessary to secure peace and security, but it is for the United Nations itself to decide. ${ }^{\text {'51 }}$

The exercise of the right of self-defence by the victim state could be potentially suspended if the UN Security Council imposes a general ceasefire upon the belligerents. In Resolution 598 (1987), for instance, the Security Council ordered a ceasefire between Iran and Iraq and demanded that both belligerents 'discontinue all military actions on land, at sea and in the air, and withdraw all forces to the internationally recognized boundaries without delay,. ${ }^{152}$ If both belligerent states comply with the UN Security Council's ceasefire, the exercise of the right of self-defence by the attacked state is suspended as a consequence of the primacy of the Security Council in the maintenance of international peace and security. But if the aggressor state rejects the ceasefire, or resumes the attack after initially complying with it, or does not withdraw its troops from

147 ILC, Responsibility of States for Internationally Wrongful Acts-Commentary (n 123) 52, art 34 (emphasis added).

148 Dinstein argues that it is only 'a legally binding decision, whereby the cessation of the defensive action becomes compulsory' that may divest the right of states to react in self-defence (Dinstein (n 1) 239), but this is too narrow a view: other measures may have that consequence as well, including recommendations, if they are complied with and manage to effectively restore international peace and security.

149 Craig Scott and others, 'A Memorial for Bosnia: Framework of Legal Arguments Concerning the Lawfulness of the Maintenance of the United Nations Security Council's Arms Embargo on Bosnia and Herzegovina' (1994) 16 Michigan J Intl L 1, 69.

150 Bowett (n 3) 196. It could be, therefore, any of the measures provided in the UN Charter, ch VII, and both recommendations and decisions: Kelsen, The Law of the United Nations (n 69) 801-02.

151 Rosalyn Higgins (n 38) 206; Gill, 'Legal and Some Political Limitations on the Power of the UN Security Council to Exercise its Enforcement Powers under Chapter VII of the Charter' (n 144) 96. But, in contrast, see Halberstam (n 144) 244; Scott (n 149) 61-62. Kelsen argues that '[i]t probably was not the intention of the legislator to confer upon the members involved in self-defense the power to decide whether the measures taken by the Council are adequate' and that ' $\mathrm{t}$ ] he idea was probably that the exercise of the right of self-defense is allowed only until the Security Council has taken the measures which the Security Council deems necessary', but this is not unambiguously stated in art 51 of the UN Charter: Kelsen, 'Collective Security and Collective Self-Defense Under the Charter of the United Nations' (n 42) 793.

152 UNSC Res 598 (20 July 1987) UN Doc S/RES/598, para 1. Demands for a ceasefire were also made by the Council in the DRC conflict, the Falklands War and the Ethiopia-Eritrea conflict. See Olivier Corten, The Law against War (Hart Publishing 2010) 473. Recently, the UN Security Council called for an immediate and unconditional ceasefire in Libya. See UNSC Res 2213 (27 March 2015) UN Doc S/RES/2213, para 1. 
territory occupied as a consequence of the armed attack, the victim state may clearly continue to defend itself, or resume to do so. ${ }^{153}$

Similarly, according to the prevailing view, the adoption of sanctions under article 41 of the UN Charter does not automatically suspend the exercise of the right of self-defence of the attacked state. ${ }^{154}$ In some cases, the Council's intention not to suspend the exercise of the right of self-defence in spite of its adopting measures has been clearly expressed, as in the case of Resolution 661 (1990): the Resolution reaffirmed 'the inherent right of individual and collective self-defence, in response to the armed attack by Iraq against Kuwait, in accordance with Article 51 of the Charter', even though at the same time the UN Security Council adopted sanctions against Iraq. ${ }^{155}$ In any case, as Iraq did not comply with that Resolution and other resolutions, the right of self-defence of Kuwait and of its allies would have not been affected even in the absence of the reaffirmation of such right in the preamble of Resolution 661 (1990). ${ }^{156}$

When the UN Security Council imposes an arms embargo towards all belligerents in an international armed conflict, this may negatively affect the right of the attacked state to defend itself. Of course, not every arms embargo is necessarily inconsistent with article 51, otherwise the Security Council could never use this measure under article $41 .^{157}$ The problem first arose in 1977 when France claimed that an arms embargo on South Africa would breach that state's right of self-defence. ${ }^{158}$ More famously, in Resolution 713 (1991), the UN Security Council adopted a comprehensive arms embargo against the entire territory of the former Yugoslavia with the consent of the federal government of Yugoslavia, in order to prevent an escalation of hostilities and to support the negotiation process. ${ }^{159}$ The embargo continued to apply even after the break-up of Yugoslavia and the independence of Bosnia and Herzegovina. As the Republic of Yugoslavia (Serbia and Montenegro) continued to provide arms and logistical support to the Bosnian Serbs at least until 1994, ${ }^{160}$ in 1993 the Bosnian government asked the UN Security Council to lift the arms embargo that prevented it from acquiring the means to exercise its right to self-defence and from reacting against the armed attack by Yugoslavia and, at least initially, Croatia. ${ }^{161}$ In spite of several General Assembly's requests, ${ }^{162}$ the Council did not lift the embargo: a draft resolution that exempted Bosnia and Herzegovina from it

153 Gill, 'Legal and Some Political Limitations on the Power of the UN Security Council to Exercise its Enforcement Powers under Chapter VII of the Charter' (n 144) 94; Corten (n 152) 479.

154 Dinstein (n 1) 238; Gill, 'Legal and Some Political Limitations on the Power of the UN Security Council to Exercise its Enforcement Powers under Chapter VII of the Charter' (n 144) 98.

155 UNSC Res 661 (6 August 1990) UN Doc S/RES/661.

156 Gill, 'Legal and Some Political Limitations on the Power of the UN Security Council to Exercise its Enforcement Powers under Chapter VII of the Charter' (n 144) 99.

157 Christine Gray, International Law and the Use of Force (3rd edn, OUP 2008) 127.

158 ibid 126.

159 UNSC Res 713 (25 September 1991) UN Doc S/RES/713.

160 Scott (n 149) 45-47.

161 President Itzebegović of Bosnia and Herzegovina declared that '[ $\mathrm{t}$ ]he arms embargo has deprived BosniaHercegovina of the right of legitimate defense': quoted in Kaghan (n 145) 768.

162 UNGA Res 47/121 (18 December 1992) UN Doc A/RES/47/121; UNGA Res 48/88 (20 December 1993) UN Doc A/RES/48/88; UNGA Res 49/10 (3 November 1994) UN Doc A/RES/49/10. 
'with the sole purpose of enabling [it] to exercise its inherent right to self-defence' was not adopted because of the abstention of nine Council members. ${ }^{163}$ The arms embargo was only lifted in Resolution 1074 (1996). ${ }^{164}$

On the other hand, when Rwanda argued that the arms embargo imposed by Resolution 918 (1994) should be lifted because of external threats to the country, the Security Council unanimously adopted Resolution 1011 (1995), by which it suspended the embargo against the Government of Rwanda. ${ }^{165}$ Resolutions 1493 (2003), 1596 (2005) and 1807 (2008) also provided for an arms embargo only against non-governmental forces operating in the Democratic Republic of the Congo (DRC) with the support of neighbouring states. ${ }^{166}$ In early 2015, the battered Libyan government and Egypt asked the Security Council to lift the arms embargo against all actors in Libya imposed in Resolution 1970 (2011) and reaffirmed in Resolution 2174 (2014) ${ }^{167}$ so that the Libyan National Army could receive military matériel and weapons to counter the 'rampant terrorism' of the 'Islamic State. ${ }^{168}$ In response, the UN Security Council requested the Sanctions Committee to consider expeditiously requests for such supply to the Libyan Government and emphasised the importance of providing support and assistance to the Government of Libya, including by providing it with the necessary security and capacity building assistance. ${ }^{169}$ Although neither the Libyan government nor Egypt expressly referred to the right of self-defence, the latter provided the former with military assistance, and the Arab League also called its members to provide all forms of support to Libya. ${ }^{170}$

The above cases show that the Bosnian precedent should not be given too much significance. Already the classical scholars of international law maintained that 'every nation has the right to those things without which it cannot preserve itself. ${ }^{\prime 71}$ Indeed, article 51 of the UN Charter would contradict itself if, on the one hand, it reaffirmed the

163 UNSC Draft Resolution (29 June 1993) UN Doc S/25997.

164 UNSC Res 1074 (1 October 1996) UN Doc S/RES/1074.

165 Gray (n 157) 127: UNSC Res 918 (17 May 1994) UN Doc S/RES/918; UNSC Res 1011 (16 August 1995) UN Doc S/RES/1011.

166 UNSC Res 1493 (28 July 2003) UN Doc S/RES/1493; UNSC Res 1596 (18 April 2005) UN Doc S/RES/1596; UNSC Res 1807 (31 March 2008) UN Doc S/RES/1807.

167 After the UN General Assembly accepted the National Transitional Council as the new Libyan Government, the Security Council adopted Resolution 2009 (2011), which allowed the transfer of arms to the new Libyan authorities under the condition that such transfers would be notified to the Sanctions Committee in advance and in the absence of a negative decision by the Committee within five working days of such a notification. See UNSC Res 2009 (16 September 2011) UN Doc S/RES/2009. Resolution 2174 (2014) restricted this regime by requiring that all supplies of arms and related materiel to Libya must be approved in advance by the Sanctions Committee. See UNSC Res 2174 (27 August 2014) UN Doc S/RES/2174; UNSC Res 1970 (26 February 2011) UN Doc S/RES/1970.

168 Declaration of the Libyan Delegate at the UN Security Council, UNSC Verbatim Record (18 February 2015) UN Doc S/PV.7387, 5. For the Declaration of the Egyptian Delegate at the UN Security Council, see UNSC Verbatim Record (18 February 2015) UN Doc S/PV.7387, 7.

169 UNSC Res 2214 (27 March 2015) UN Doc S/RES/2214, paras 7-8.

170 Declaration of the Egyptian Delegate at the UN Security Council (n 168) 7.

171 Wolff (n 10) 23-24, paras 32, 34. See also Vattel (n 10) book I, ch II, 88, s 18. 
inherent right of self-defence but, on the other hand, it allowed a state to be deprived of the means to exercise it. ${ }^{172}$ As has been observed, the UN Security Council

cannot prevent a State which it cannot or will not defend, from defending itself. Neither can the Council prevent a State which lacks the capacity to defend itself, from receiving such assistance from third States as will enable it to defend itself or at least enhance its ability to do so. ${ }^{173}$

An arms embargo adopted by the UN Security Council against all belligerents to prevent an aggravation of the crisis, then, will not be prima facie inconsistent with the inherent right of self-defence of the attacked state. But if the UN Security Council's measures have unequal effects and result in depriving a state of its right to defend itself without at the same time providing it with equivalent protection, such measures are superseded by the inherent right of self-defence, which is not 'impaired' by any UN Charter provision, including chapter VII or article 103. ${ }^{174}$

To be clear, the question of whether UN Security Council resolutions may negatively affect the exercise of self-defence by a state arises only in relation to states victims of an armed attack, and not to states responsible for violations of article 2(4) of the UN Charter or a threat to the peace. Resolution 1907 (2009) providing for an arms embargo on Eritrea for its support to armed groups in Somalia, for instance, did not impair the right of self-defence of that country, as it was not the victim of an armed attack. ${ }^{175}$ The District Court of The Hague also had to examine the defence invoked by the defendant, the chairman of a Dutch company that had allegedly transported and imported arms in Liberia in 2001-03 on behalf of the Charles Taylor regime, against the charge of the violation of the sanctions regime decided by the UN Security Council in Resolution 1341 (2001) and 1408 (2002). ${ }^{176}$ The defendant invoked article 51 of the UN Charter claiming that Liberia had to defend itself against attacks by rebels and that therefore Liberia was entitled to receive the weapons provided by the defendant in spite of the embargo. ${ }^{177}$

172 As has been seen, however, self-defence does not include the right to use prohibited weapons (see above).

173 Gill, 'Legal and Some Political Limitations on the Power of the UN Security Council to Exercise its Enforcement Powers under Chapter VII of the Charter' (n 144) 103.

174 The same conclusion would be reached by arguing that the right of self-defence is a jus cogens rule or that art 103 limits the prevalence of UN Charter obligations only to conflicting treaty law provisions and does not also extend to customary international law rules like self-defence. See Gaetano Arangio-Ruiz, 'Article 39 of the ILC First-Reading Draft Articles on State Responsibility' (2000) 83 Rivista di Diritto Internazionale 747, 752; Karl Zemanek, 'The Legal Foundations of the International System' (1997) 266 $\mathrm{RdC} 1,232$. As far as the former argument is concerned, it can be recalled that, in his Separate Opinion to the ICJ's Provisional Measures Order on the Application of the Genocide Convention, Judge Lauterpacht suggests that para 6 of Resolution 713 (1991) is invalid, and therefore not binding on member states, because it was in contrast with the jus cogens prohibition of genocide. See Application of the Convention on the Prevention and Punishment of the Crime of Genocide (Bosnia and Herzegovina $v$ Serbia and Montenegro) (Provisional Measures, Order of 13 September 1993) [1993] ICJ Rep 325, para 103 (Judge Lauterpacht). His conclusions could be extended to self-defence if one assumes that this is also a jus cogens norm.

175 UNSC Res 1907 (23 December 2009) UN Doc S/RES/1907.

176 UNSC Res 1341 (22 February 2001) UN Doc S/RES/1341; UNSC Res 1408 (6 May 2002) UN Doc S/RES/1408.

177 Guus Kouwenhoven case, District Court of The Hague (7 June 2006) Count 5, s 11. 
The District Court rejected this plea on the ground that, at the time of the offences, the UN Security Council had already taken measures necessary to maintain international peace and security under Resolution 1343 (2001) also in reaction to Liberia's support for armed groups operating in neighbouring countries, in particular Sierra Leone, which amounted to a threat to international peace and security in the region. ${ }^{178}$ As Liberia was responsible for such destabilisation, it was not in a situation of self-defence.

A final point concerns the question whether states have a right of self-defence against UN Security Council authorised enforcement operations. The answer is negative: self-defence only applies to reactions against unlawful uses of force. ${ }^{179}$ Indeed, unlike a state of necessity, self-defence always implies the commission of an internationally wrongful act, as it is a reaction against a serious violation of article 2(4) of the UN Charter amounting to an 'armed attack'. A use of force authorised by the UN Security Council, however, is not a violation of article 2(4) of the UN Charter. The principle of incompatible rights, ie 'one party's right to act implies a corresponding denial of the right of those who are affected to resist the rightful use of force, ${ }^{180}$ applies then not only when a state exercises the right of self-defence, ${ }^{181}$ but also when the UN Security Council authorises military intervention under chapter VII. If the operation exceeds the UN Security Council's mandate, however, the right of self-defence cannot be excluded against the actions exceeding it. ${ }^{182}$

\section{Conclusion}

Of all the rights that were once considered 'fundamental', self-defence is probably the one to which states have proved to be most attached. This is demonstrated by its history and by its qualification as an 'inherent right' in article 51 of the UN Charter. This article has applied the interpretive rules contained in the VCLT to determine what the 'inherent' right means in article 51 and what legal consequences this qualification entails. This article concludes that the qualification of self-defence as 'inherent' in article 51 of the UN Charter epitomises the fact that self-defence is a corollary of statehood as presently defined in positive law, as it is functional to preserving its constitutive elements. It has, to use the ICJ's words in the North Sea Continental Shelf judgment, 'an a priori character of so to speak juristic inevitability. ${ }^{183}$ Self-defence is also an essential means to enforce

178 UNSC Res 1343 (7 March 2001) UN Doc S/RES/1343.

179 Lamberti Zanardi (n 21) 124.

180 Fletcher and Ohlin (n 9) 46-47. See also Dinstein (n 1) 190.

181 For example, see Bowett (n 3) 53: 'Against the lawful exercise of a right of self-defence there can be no right of self-defence in the state claiming political independence'.

182 Ilias Bantekas, 'The Permissibility of Defiance and Self-Defence against Chapter VII Authorisations: When and Why' (2007) 12 ARIEL 3, 14-15. This situation may have arisen in Libya in 2011, where Resolution 1973 (2011) only authorised states to use all necessary means 'to protect civilians and civilian populated areas under threat of attack in the Libyan Arab Jamahiriya, including Benghazi': UNSC Res 1973 (17 March 2011) UN Doc S/RES/1973, para 4.

183 North Sea Continental Shelf (n 67) para 37. 
a fundamental provision of the international legal order, ie the prohibition of the use of armed force in international relations.

This article has also demonstrated that, from the inherent character of self-defence, important legal consequences arise: the right of self-defence cannot be alienated and it takes precedence over other international obligations, although not over those specifically intended to limit the conduct of states in armed conflict and over non-derogable human rights provisions. The exercise of the right, however, may be delegated to other states or be submitted to limitations under both customary international law and treaty law, but such limitations cannot go as far as to deprive a state of the right itself.

In the end, then, far from being irrelevant, the 'inherent' character of self-defence is a potent reminder of the fact that states still hold a powerful grip on the international legal order. 